\title{
AKADEMIESE STEUN BY DIE MILITÊRE AKADEMIE : DIE AANSPREEK VAN ANDERSHEDE IN DIE SA WEERMAG
}

\author{
DEUR MEV L.M. SMITH*
}

\section{INLEIDING}

Die Suid-Afrikaanse gemeenskap is blootgestel aan snelle veranderinge wat noodwendig ' $n$ neerslag vind in die SA Weermag en die Militêre Akademie op Saldanha. Dit is egter nie net die veranderinge wat hul invloed laat geld nie, maar ook die gebeure wat die veranderinge voorafgegaan het.

Die Fakulteit Krygskunde aan die Universiteit van Stellenbosch (soos enige ander Suid-Afrikaanse tersiêre opleidingsinstansie) moet dus hul taak volvoer met inagneming van ' $n$ buitengewone geskiedenis en die eise van ' $n$ dinamiese toekoms.

Studente wat aanmeld vir ' $n$ B. Mil. graad by bogenoemde fakulteit het deel aan sekere gemeenskaplikhede, maar ook andershede wat spruit uit elk se agtergrond. "Andersheid" word omskryf as die persoonlike verskille wat elke individu of groep uniek maak. Dit is belangrik dat die leser kennis neem daarvan dat elke student van gelyke waarde geag word en dat "andersheid" nie sinoniem is vir "minderwaardigheid" nie.

Die erkenning van sulke andershede in

a. omvang en kwaliteit van sekondêre opleiding;

b. etnisiteit en kultuur, asook

c. vermoëns en vaardighede van persone binne verskillende of dieselfde groeperings; en

d. persoonlike agtergrond en omstandighede het gelei tot ' $n$ behoefte aan tersiêrgerigte akademiese steunprogramme ten einde regstelling van geïdentifiseerde akademiese en ander leemtes te bewerkstellig.

Indien die unieke militêre karakter van die Fakulteit Krygskunde vergelyk word met die "siviele" karakter van ander fakulteite in Suid-Afrika, word dit duidelik dat bestaande akademiese steunen "oorbruggings"programme nie summier van toepassing gemaak kon word op ' $n$ teikengroep in die Krygskunde nie. Die nodige aanpassings en vernuwing moes vanuit die SA Weermagsmilieu bedryf word deur lede wat die weermagkultuur en die organisasie se behoeftes verstaan en dit op ' $n$ voltydse grondslag kon doen. Die SuidAfrikaanse Weermag doen dus tans baanbrekerswerk op die gebied van voltydse tersiêre akademiese steun, aangesien dit die eerste keer in sy geskiedenis is dat ' $n$ steunprogram geimplementeer word wat spesifiek vir die organisasie ontwerp is deur lede van die organisasie.

Die stigting van ' $n$ Departement vir Akademiese Steundienste in 1991 het die nodige strukture geskep waardeur daar in bogenoemde behoefte voldoen kon word.

\section{BESTEK}

Aanvanklik word die rasionaal agter akademiese steunverlening bespreek en die didaktiese werkswyse wat by die Militêre Akademie gevolg word. Daarna word die aard van tersiêre akademiese steun aan die Fakulteit Krygskunde aan die Universiteit van Stellenbosch bespreek. Sodanige steun word vir die bespreking onderverdeel in die Militêre Akademie-voorbereidingskursus 
en die Akademiese Steunprogram. Die praktiese toepassing van die steunprogram deur middel van "steunbane" by die Militêre Akademie word uitgewys, asook die bykomende dienste wat deur die Departement vir Akademiese Steundienste aan dosente en studente gelewer word. Die artikel word afgesluit met 'n slotbeskouing oor tersiêre akademiese steun in die Suid-Afrikaanse Weermag.

\section{RASIONAAL}

Die Militêre Akademie-student verteenwoordig die belegging van die Staat in die toekoms van die SA Weermag se offisierskorps en dien uiteraard as die sterkste motivering vir akademiese steun.

Die Departement vir Akademiese Steundienste stel hom dus ten doel om aan elke student die beste moontlike geleentheid te bied om 'n graadkursus binne die minimum aantal voorgeskrewe studiejare en sonder 'n verlaging in bestaande akademiese standaarde te slaag.

Die bekende "gelyke beregtiging" programme ("affirmative action programmes") vanuit die Verenigde State van Amerika, wat aanvanklik as grondslag vir oorbruggingsprogramme in Suid-Afrika gedien het, het hulself mettertyd as onvoldoende bewys. Dit mag juis wees omrede sulke programme een groep persone (sogenaamd minder bevoorregte) ten koste van ' $n$ ander (sogenaamd meer bevoorregte) groep probeer bevorder het.

Die aanname is gemaak dat alle individue binne ' $n$ groep noodwendig meer of minder bevoorreg is. Die Militêre Akademie het besluit om ' $n$ benadering te volg waarin individualisering plaasvind, sonder om groepe te etiketteer op ' $n$ wyse wat as paternalisties ervaar kon word. Die student word op meriete as menswaardig erken en is nie die ontvanger van toegifte ("handouts") nie.

Die ervaring van die Universiteit van Kalifornië (Berkeley, VSA) kan in hierdie verband aangehaal word. Daar is gevind dat akademiese steun, wanneer dit aangebied is op grond van etnisiteit, deur die betrokke studente verwerp is en hul geen deel daaraan wou hê nie. Die redes wat aangevoer is deur die studente is dat hul in die onderskeie hoërskole gesien is as sterk kandidate vir tersiêre studie en deel was van ' $n$ akademiese elite. Aanbiedinge van hulp aan etniese groeperings is gesien as rassisties en "bedoel vir iemand anders".'

Deur bestaande akademiese standaarde te handhaaf en alle studente aan die Akademie van akademiese steun te bedien in die mate waarin leemtes geïdentifiseer is, word ' $n$ diens gelewer sonder om enigeen uit te sonder en met die meeste steun aan diegene met die grootste behoefte, ongeag wie die student is.

Gevolglik tref die Militêre Akademie geen ander onderskeid tussen studente nie as ' $n$ individualisering ten opsigte van die regstelling van akademiese leemtes. Daar word gewaak daarteen om weer eens groeperings te skep waarin 'n "klein apartheid" sy beslag vind en sodoende die taak van die SA Weermag bemoeilik om lede en stelsels te integreer.

\section{DIDAKTIESE WERKSWYSE}

Die akademiese steunprogram het as grondslag ' $n$ benadering dat die andershede van studente aangespreek word met die gemeenskaplikhede as vertrekpunt. Waar die tersiêre student normaalweg vanuit ' $n$ teoretiese lesing ' $n$ praktiese toepassing sou maak, word hy gedurende die akademiese steunprogram vanaf die praktiese situasie (gemeenskaplikheid) gelei binne ' $n$ konsentriese ontdekkingsproses na die teoretiese beginsels onderliggend aan die verskynsel wat manifesteer in die praktyk. Teoretiese kennis word dus nie summier voorveronderstel nie en die spesifieke student bepaal uiteindelik die areas wat aangespreek word ten einde regstelling van akademiese leemtes (andershede) te doen.

Die selfwerksaamheidsbeginsel en betrokkenheid van studente geld deurgaans en die vorming van informele steun- en studiegroepe word aktief aangemoedig. Die tradisionele for- 
mele lesingmetode word min gevolg deur dosente aan die Departement vir Akademiese Steundienste en deelnemende opleidingsmetodes, soos sindikaatgroepe en ander kleingroepaktiwiteite, word met studente gebruik. Die student is en bly verantwoordelik en verantwoordbaar vir sy eie vordering.

Erkenning van inisiatiewe en kritiese denke en volgehoue terugvoer oor aktiwiteite deur die dosent dra verder by tot die bevordering van prestasiemotivering en akademiese waagmoed by die student. Uiteindelik vervul die dosent die rol van mentor en fasiliteerder van ' $n$ ontdekkingsproses binne die studieveld.

Die volledige kurrikulering van die program en werksaamhede op mikrovlak (deur die dosent) en op mesovlak (deur die departementshoof) verseker die handhawing van eenvormige standaarde binne kleingroepaktiwiteite.

\section{AKADEMIESE STEUN}

'n Geïntegreerde akademiese steunprogram word gevolg waarin die klem veral op die eerstejaarstudent val, synde die groter akademiese risiko te verteenwoordig. Studente uit ander studiejare met toepaslike probleme word merendeels op individuele basis hanteer, na verwysing deur 'n dosent aan die Fakulteit Krygskunde of aanmelding deur die lid self.

Die leemtes wat in hoofsaak aangespreek word gedurende die steunprogram is soos volg:

a. Gebrekkige taalbedrewenheid in beide amptelike tale.

b. Ontoereikende lees-, studie- en denkvaardighede.

c. Ontoereikende lewensvaardighede wat tot aanpassingsprobleme lei.

d. Gevoelens van isolasie by minderheidsgroepe.

Die akademiese steunprogram neem ' $n$ aanvang in die kalenderjaar voor die begin van die eerste akademiese jaar met 'n Militêre Akademie-voorbereidingskursus (Deel I) van ses weke. Die Suid-Afrikaanse Weermag is die enigste tersiêre inrigting wat tans ' $n$ voorbereidingskursus kan aanbied in die kalenderjaar voor inskrywing by die Universiteit.

Die Militêre Akademie-voorbereidingskursus word dan opgevolg gedurende die eerste akademiese studiejaar met die Steunprogram (Deel II) wat die hele jaar duur en alle eerstejaarstudente betrek.

\section{VOORBEREIDINGSKURSUS}

Die voorbereidingskursus is die oorgang tussen die Senior Sertifikaateksamen en die aanvang van die eerste akademiese studiejaar van die B.Mil-graad. Dit is dus gemik op die voorbereiding van spesifieke voornemende hoër-risiko studente wat geïdentifiseer is op grond van:

a. Taalbelemmeringe (agterstand in leesbegrip, woordeskat en verbalisering van verworwe kennis) in een of albei die amptelike tale op tersiêre vlak.

b. Studente met potensiële studieof aanpassingsprobleme.

c. Studente met ' $n$ natuurwetenskaplike aanleg en agtergrond, wat deur korpsbepalings verplig word om 'n geesteswetenskaplike studierigting te volg, en omgekeerd.

d. Studente wat probleme ondervind met die optimale verwesenliking van hul akademiese potensiaal.

e. Leemtes wat spruit uit diverse skolestelsels, persoonlike omstandighede en interetniese verskille.

Die voorbereidingskursus bestaan eerstens uit 'n algemene vaardigheidsfase met die fokus op regstelling van taal-, denk-, studie- en lewensvaardigheidsleemtes. Tweedens word vakgerigte steun verleen in vakke waarin die voornemende student leemtes vertoon, asook ' $n$ bekendstelling aan akade- 
miese hulpbronne.

Die benadering is dus gerig op die erkenning van bestaande vaardighede en die ontwikkeling daarvan om te kan aanpas by die akademiese en kultuureise van ' $n$ moderne weermag. Waar hierdie vaardighede ontoereikend is of ontbreek, word leemtes aangespreek en die student voorberei deur ' $n$ bekendstelling aan die grondbeginsels van die vak.

Studente word tydens die duur van die voorbereidingskursus getakseer in 'n poging om potensiaal te bepaal en te ontwikkel. Indien die student die voorbereidingskursus suksesvol aflê, word hy of sy aanbeveel vir toelating tot die B. Mil-graad.

\section{STEUNPROGRAM}

Die Militêre Akademie-steunprogram (Deel II) geskied in samewerking met die departementshoofde en dosente in elke vakgebied. Die betrokke lede van die Fakulteit Krygskunde verleen vakgerigte akademiese steun aan eerstejaarstudente op 'n weeklikse basis gedurende periodes wat daarvoor binne elke vak opsygesit is. Daarby is weeklikse steunprogramperiodes opsygesit vir eerstejaarstudente vir gebruik deur die Departement vir Akademiese Steundienste.

Taalopleiding in Afrikaans en Engels en opleiding in die ontwikkeling van skryfen denkvaardighede word aangebied vir die duur van die eerste akademiese jaar. Daarby word korter kursusse aangebied in leesverbetering, studiemetodes, rekenaargeletterdheid, lewens- en aanpassingsvaardighede en ander onderwerpe wat ' $n$ behoefte van die teikengroep verteenwoordig.

Dit is prakties moontlik om onderskeid te tref tussen die behoeftes van ' $n$ groot groep studente deur ' $n$ stelsel van "steunbane". Die studentegroep is onderverdeel in kleingroepe wat verskillende "bane" op 'n gegewe tyd volg. Deur die herhaling van opleidingsmodules en kursusse in verskillende "steunbane" kan die nodige soepelheid bewerkstellig word om gedifferensiëerde opleiding aan studente te bied deur die loop van die akademiese jaar. Dit laat ook die nodige ruimte om akademiese behoeftes van dosente aan te spreek en veranderinge aan die program aan te bring.

Die Departement vir Akademiese Steundienste lewer 'n diens aan die studente en die dosente van die Militêre Akademie. Skakeling op tersiêre vlak en die byhou van inligting oor opleidingstendense en nuwe ontwikkelinge in die veld vorm deel van die taak van die Departement.

Die Akademie se Interne Studentevoorligtingsdiens en die Taaldiens is verder deel van bogenoemde Departement. Individuele dienslewering aan alle studente en dosente word deurlopend deur hierdie twee dienste verskaf.

\section{SLOT}

Akademiese steunverlening op tersiêre vlak in Suid-Afrika is ' $n$ uitdagende gebied en stel besondere eise aan die instansie wat dit aanbied. Die saamsnoer van die geskiedenis en die toekoms in die hede is ' $n$ taak wat ' $n$ besondere inset van 'n toegewyde fakulteit en organisasie verg. Dit is slegs deur die andershede aan te spreek, dat ons in Suid-Afrika 'n situasie kan bewerkstellig waarin ons deel het aan ' $n$ gemeenskaplike akademiese toekoms.

Die Suid-Afrikaanse Weermag het homself weer eens bewys as 'n leier op talle gebiede, deur nie terug te deins vir vooruitgang op akademiese gebied nie, maar ' $n$ unieke bydrae tot die veld te lewer.

\section{* Mev Lana Smith is die Hoof van die Departement vir Akademiese Steun- dienste aan die Fakulteit Krygskunde, Universiteit van Stellenbosch.}

1. Watkins, B. Many campuses now challenging minority students to excel in Mathematics and Science, in Chronicle of Higher Educationcaton. 14 Junie 1989. p A 16 

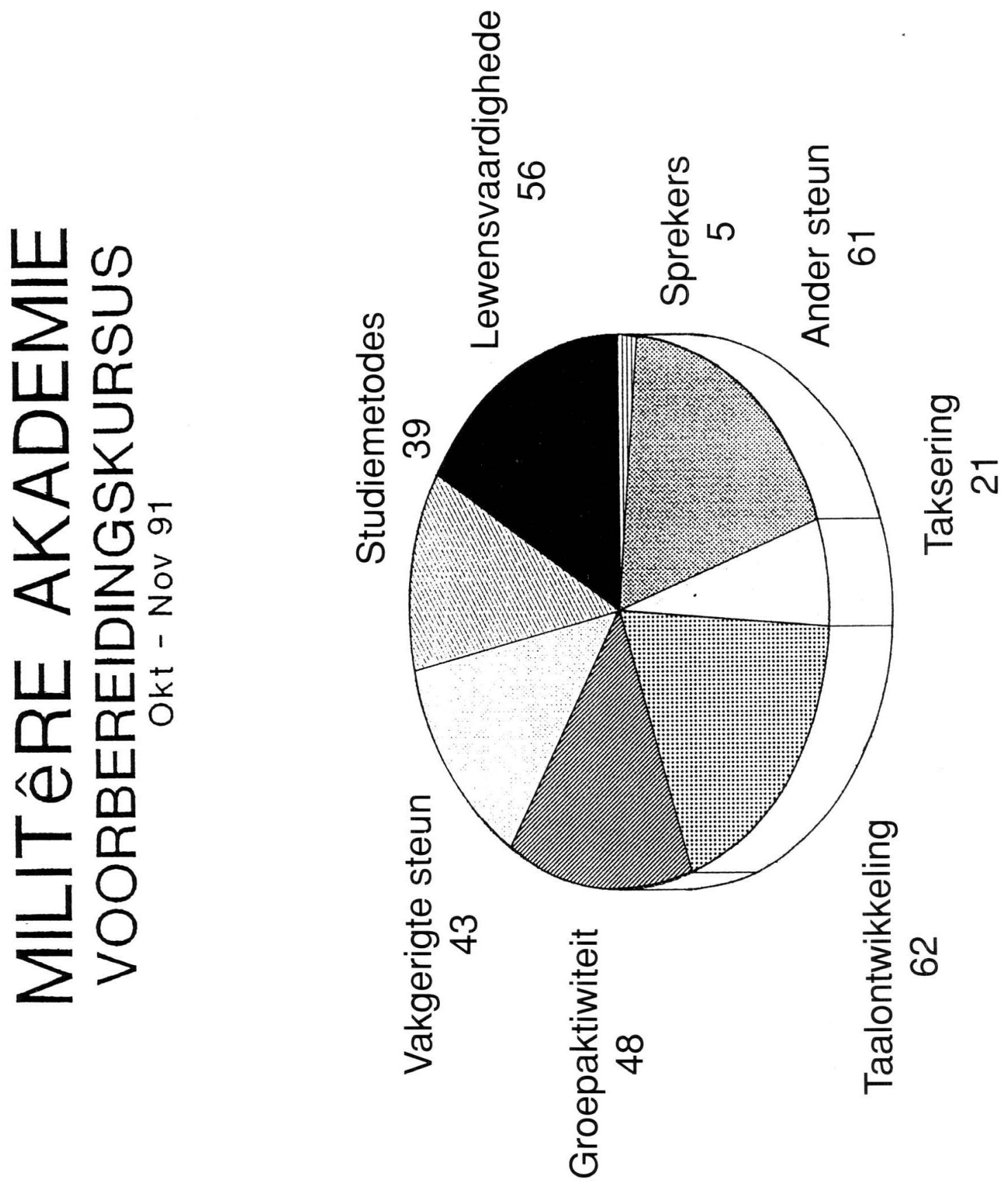